\title{
EFEKTIVITAS MODEL PEMBELAJARAN DISCOVERY LEARNING TERHADAP KEMAMPUAN LITERASI MATEMATIKA DI SEKOLAH DASAR
}

\author{
Rida Fironika Kusumadewi \\ Nuhyal Ulia \\ Nesti Ristanti \\ Prodi Pendidikan Guru Sekolah Dasar, Fakultas Keguruan dan Ilmu Pendidikan \\ Universitas Islam Sultan Agung Semarang \\ Email: ridafkd@unissula.ac.id
}

Artikel diterima: 6 September 2018; disetujui: 31 Mei 2019

\begin{abstract}
An innovative learning model is very influential on mathematical literacy skills. Mathematical literacy skills, indirectly learn about several aspects, one of which is identifying mathematical aspects in mathematics reading. This study aims to prove the effectiveness of the discovery learning model of mathematical literacy abilities. This study uses experimental research. The design used is the non-equivalent posttest-only control group design which is one of the Quasi Experimental Design research designs. The results of the final data hypothesis were then analyzed by the $t$ test. The results of the $t$ test show $t_{\text {count }} 3.16>t_{\text {table }} 2.04$, meaning that the ability of mathematical literacy with the discovery learning model is better than the teacher centered model.
\end{abstract}

Keywords: innovative, mathematical literacy skills, discovery learning

\begin{abstract}
Abstrak: Model pembelajaran yang inovatif sangat berpengaruh terhadap kemampuan literasi matematika. Kemampuan literasi matematika, secara tidak langsung mempelajari tentang beberapa aspek, salah satunya mengidentifikasi aspek matematis dalam bacaan matematika. Penelitian ini bertujuan untuk membuktikan efektivitas model discovery learning terhadap kemampuan literasi matematika. Penelitian ini menggunakan penelitian eksperimen. Desain yang digunakan adalah the non-equivalent posttest-only control grup design yang merupakan salah satu dari desain penelitian Quasi Experimental Design. Hasil hipotesis data akhir kemudian dianalisis dengan uji t. Hasil dari uji t menunjukkan $\mathrm{t}_{\text {hitumg }} 3,16>\mathrm{t}_{\text {tabel }}$, 2,04, diartikan bahwa kemampuan literasi matematika dengan model discovery learning lebih baik daripada model teacher centered.
\end{abstract}

Kata Kunci : inovatif, kemampuan literasi matematika, discovery learning

Bangsa Indonesia merupakan bangsa yang berpenduduk besar dengan besarnya penduduk, bangsa Indonesia bisa menjadi bangsa yang maju atau sebaliknya ini semua tergantung dari kualitas sumber daya manusia..Undang-undang No.20 Tahun 2003 tentang sistem pendidikan nasional mengatakan bahwa "Pendidikan memiliki fungsi untuk menumbuhkan kemampuan dan membentuk watak yang bermartabat dalam usaha mencerdaskan kehidupan bangsa, bertujun untuk bekembangnya potensi siswa supaya menjadi manusia yang beriman dan bertakwa kepada Tuhan Yang Maha Esa, berakhlak mulia, sehat, berilmu, cakap, kreatif, mandiri, dan menjadi warga negara yang demokratis serta bertanggung jawab". Dalam proses mewujudkan kecerdasan kehidupan bangsa, pendidikan di Indonesia memiliki beberapa 
kurikulum yang digunakan untuk mengatur sistem pembelajaran yang berlangsung di sekolah khususnya di tingkat sekolah dasar.

Salah satu materi dasar disekolah dasar adalah pelajaran matematika. Matematika merupakan suatu ilmu deduktif, aksiomatik, formal, hierarkis, abstrak, bahasa simbol yang padat anti dan semacamnya sehingga para ahli matematika dapat mengembangkan sebuah sistem matematika (Karso, dkk, 2009:1.4). Matematika juga merupakan salah satu mata pelajaran yang berperanpenting sebagai sarana berpikir deduktif, logis dan ilmiah pada satuan pendidikan tingkat sekolah dasar. Mengingat peranan matematika yang sangat penting, maka para murid mutlak dituntut untuk menguasainya, khususnya pada tingkat sekolah dasar kelas V. Seringkali dikatakan matematika merupakan mata pelajaran yang sangat membosankan dan sulit dipahami oleh siswa, hal ini disebabkan karena kurangnya perhatian guru dalam pentingnya memberikan inovasi dalam pembelajaran dan kurangnya minat membaca sebelum pembelajaran dimulai.

Pada dasarnya membaca sebelum pembelajaran dimulai itu sangat penting. Berdasarkan uraian faktafakta tersebut dikuatkan dengan hasil wawancara yang dilakukan dengan guru kelas V. Beliau mengungkapkan bahwa inovasi dalam pembelajaran masih sangat minim dilaksanakan oleh guru, selain itu literasi di SDN Kalisari 1 masih kurang dan belum berjalan dengan baik terutama pada pembelajaran matematika di kelas V. Hal ini juga dikuatkan dari hasil dokumentasi ulangan harian matematika siswa kelas VA pada materi pecahan diketahui bahwa 14 siswa dari 31 siswa dengan persentase $45,16 \%$ sedangkan hasil ulangan harian matematika siswa kelas VB pada materi pecahan ada 16 siswa dari 31 siswa dengan persentase $51,61 \%$ yang belum mencapai nilai ketuntasan minimal sebesar 70 sesuai dengan kriteria ketuntasan minimal yang digunakan di SDN Kalisari 1 dimana persentase tersebut sebagai acuan rendahnya kemampuan literasi matematika kelas V di SDN Kalisari 1.

Model pembelajaran discovery learning adalah model mengajar yang mengatur jalanya pembelajaran menjadi sedemikian rupa sehingga anak memperoleh pengetahuan yang sebelumnya belum diketahui dan tidak melalui pemberitahuan, namun sebagian atau seluruhnya ditemukan sendiri (Azhari, 2015). Sedangkan Hosnan (2013) menerangkan bahwa discovery learning merupakan salah satu model untuk mengembangkan cara belajar siswa aktif menemukan sendiri, menyelidiki sendiri, maka hasil yang diperoleh akan setia dan tahan lama dalam ingatan, tidak akan mudah dilupakan oleh siswa. Berdasarkan konteksnya, keterkaitan dalam kegiatan sehari-hari siswa akan lebih memahami tentang literasi (Hasnawati, 2016). Anak juga bisa belajar berpikir analisis dan mencoba memecahkan sendiri masalah yang dihadapi. Dapat disimpulkan bahwa model discovery learning merupakan suatu model yang inovatif yang mampu menjadikan siswa berfikir secara aktif, bekerja sendiri, dan mencoba menyelesaikan permasalahan yang telah dihadapi sendiri dalam kehidupan sehari hari. Hal ini juga dipertegas oleh Bruner dalam teorinya yang mengemukakan "bahwa suatu pembelajaran dikatakan baik jika guru memberi kesempatan kepada siswa untuk dapat mencari dan menemukan konsep sendiri dengan contoh yang ada dikehidupan seharihari" (Lestari dan Yudhanegara, 2015:33). Teori ini menekankan bahwa dalam proses pembelajaran siswa diberikan kesempatan untuk menemukan sendiri konsep yang dipelajarinya. Proses penemuan konsep itu dapat dilakukan melalui sebuah media pembelajaran.

Media pembelajaran digunakan dalam rangka mengefektifkan komunikasi dan interaksi antara guru dan siswa dalam proses pembelajaran disekolah (Kusumadewi,2017). Mediapembelajaranyang dapat digunakan dalam menemukan konsep tersebut yang berkaitan dengan kemampuan literasi matematika salah satunya adalah dengan menggunakan komik. Penggunaan model pembelajaran discovery learning berbantuan media komik ini diharapkan mampu menumbuhkan kemampuan literasi matematika siswa yang ditandai dengan siswa mampu memahami simbol-simbol matematika serta dapat menemukan konsep sendiri yang kemudian dapat menyimpulkan isi bacaan serta dapat mengemukakan pendapatnya mengenai bacaan tersebut. Hal ini sesuai dengan salah satu tahapan yang dikemukakan oleh Bruner yaitu pada tahap simbolik. "Menurut Bruner, pada tahap ini berlangsung pada umur 8 tahun keatas, yaitu tahapan ketika seseorang sudah dapat memahami simbol dan konsep serta memiliki ide yang sangat berpengaruh terhadap kemampuan dalam berbahasa dan berlogika" (Lestari dan Yudhanegara, 2015:34).

Soal-soal yang berhubungan dengan literasi pada studi PISA menuntut pada kemampuan penalaran dan pemecahan masalah yang menekankan 
pada berbagai masalah dan situasi dalam kehidupan sehari-hari (Fathani, 2016). Belajar dalam PISA berhubungan dengan konsep belajar sepanjang hayat, dimana penilaian kompetensi siswa tidak dibatasi dengan konsep belajar yang sesuai dengan kurikulum, melainkan juga motivasi belajar, konsep diri yang ada pada diri siswa, dan strategi belajar yang diterapkan. "PISA menerangkan bahwa terdapat 7 variabel dalam literasi yaitu : komunikasi, matematisasi, menyajikan kembali, menalar dan memberi alasan, menggunakan strategi, menggunakan simbol, serta menggunakan alat matematika" (Pulungan, 2014). Dari uraian diatas, tujuan dari penelitian ini adalah untuk mengetahui efektivitas model discovery learning terhadap kemampuan literasi matematika.

\section{METODE}

Penelitian ini menggunakan penelitian eksperimen. Desain yang digunakan dalam penelitian eksperimen ini adalah the nonequivalent posttest-only control grup design yang merupakan salah satu dari desain penelitian Quasi Experimental Design. Penelitian ini terdapat dua kelompok. Kelompok pertama diberi perlakuan (X) disebut kelas eksperimen dan yang lain tidak diberi perlakuan disebut kelas kontrol. Kemudian dua kelompok tersebut diberi posttest $(\mathrm{O})$.

Populasi dalam penelitian ini adalah kelas VA dan VB SDN Kalisari 1 yang kemudian dari masingmasing kelas diambil sampel untuk penelitian. Pengambilan sampel ini menggunakan teknik simple random sampling. Sampel yang diambil masing-masing sebanyak 31 siswa.

Instrument dalam penelitian ini adalah tes, wawancara dan dokumentasi. Tes digunakan untuk pengambilan data variabel dependen yaitu kemampuan literasi matematika siswa. Instrument tes harus memenuhi syarat sebagai alat ukur yang baik. Alat ukur yang digunakan yaitu uji validitas, uji reliabilitas, uji daya pembeda dan uji taraf kesukaran sehingga nantinya akan diperoleh soal yang layak untuk penelitian. Selain tes, wawancara dan dokumentasi juga digunakan untuk mengetahui kodisi awal siswa, permasalahan dan data awal siswa.

Data awal siswa diperoleh dari hasil ulangan harian matematika kelas V yang kemudian dianalisis datanya dengan menggunakan uji normalitas, uji homogenitas, dan uji kesamaan dua rata-rata. Setelah mengetahui permasalahan yang ada di kedua kelas tersebut kemudian kedua sampel diberi perlakuan yang berbeda. Perlakuan yang berbeda ini dilakukan untuk mengetahui apakah perlakuan yang digunakan pada kelas ekperimen lebih baik dari pada dikelas kontrol. Setelah kedua sampel diberi perlakuan yang berbeda maka dilakukan tes akhir untuk memperoleh data yang diperlukan dalam penelitian, kemudian dilakukan analisis data akhir. Anaisis data akhir ini mengunakan uji normalitas, uji homogenitas dan uji hipotesis.

\section{HASIL}

Berdasarkan hasil penelitian dan analisis data yang telah dilakukan menunjukkan bahwa kemampuan literasi matematika di kelas V SDN Kalisari 1 dengan menggunakan model pembelajaran discovery learning lebih baik dari pada dengan mengunakan model teacer centered. Hal ini dapat dilihat dari hasil rata-rata data pada kelas eksperimen yang menggunakan model discovery learning dan hasil rata-rata pada kelas kontrol yang menggunakan model ceramah. Rata-rata kemampuan literasi matematika dari kelas eksperimen adalah 80,71 dan rata-rata kemampuan literasi matematika dari kelas kontrol adalah 70,26. Uji hipotesis yang sudah dilakukan juga menunjukkan bahwa kemampuan literasi matematika dengan menggunakan model discovery learning lebih baik dari pada dengan menggunakan model teacher centered. Hal ini dapat dibuktikan dengan $\mathrm{t}_{\text {hitung }}>\mathrm{t}_{\text {tabel }}, \mathrm{t}_{\text {hitung }}=3,16$ dan $\mathrm{t}_{\text {tabel }}=$ 2,04 yang artinya $\mathrm{H}_{0}$ ditolak dan $\mathrm{H}_{\mathrm{a}}$ diterima. Adapun hasil dari indikator kemampuan literasi matematika dapat dilihat pada Tabel 1.

Tabel 1 menunjukkan bahwa pencapaian indikator kemampuan literasi matematika di kelas eksperimen pada aspek siswa dapat mengidentifikasi aspek-aspek matematis yang terdapat dalam bacaan matematika, siswa dapat menyusun komposisi dengan tepat yang terdapat dalam bacaan matematika sesuai konsep matematika, siswa merancang dan menerapkan strategi dalam memecahkan masalah pada bacaan matematika dan siswa dapat membuat generalisasi berdasarkan hasil penerapan prosedur matematika termasuk kedalam kategori baik. Hal ini sesuai dengan kriteria ketuntasan minimal yang digunakan di SDN Kalisari 1, yaitu 70. Sebaliknya pencapaian indikator kemampuan literasi matematika di kelas kontrol pada tiga aspek pertama, termasuk kedalam kategori baik, sedangkan pada aspek keempat termasuk dalam kategori tidak baik. 
Tabel 1. Pencapaian Indikator Kemampuan Literasi Matematika pada kelas eksperimen dan kelas kontrol

\begin{tabular}{|c|c|c|c|c|c|}
\hline \multirow{2}{*}{ No } & \multirow{2}{*}{ Indikator } & \multicolumn{2}{|c|}{ Hasil Pencapaian Indikator } & \multicolumn{2}{|c|}{ Persentase Pencapaian (\%) } \\
\hline & & Kelas Eksperimen & Kelas Kontrol & Kelas Eksperimen & Kelas Kontrol \\
\hline 1 & $\begin{array}{l}\text { Siswa dapat mengidentifikasi aspek- } \\
\text { aspek matematis yang terdapat dalam } \\
\text { bacaan matematika }\end{array}$ & 267 & 238 & $86,13 \%$ & $76.77 \%$ \\
\hline 2 & $\begin{array}{l}\text { Siswa dapat menyusun komposisi den- } \\
\text { gan tepat yang terdapat dalam bacaan } \\
\text { matematika sesuai konsep matematika }\end{array}$ & 388 & 338 & $83.44 \%$ & $72.69 \%$ \\
\hline 3 & $\begin{array}{l}\text { Siswa merancang dan menerapkan } \\
\text { strategi dalam memecahkan masalah } \\
\text { pada bacaan matematika }\end{array}$ & 372 & 334 & $80 \%$ & $71,83 \%$ \\
\hline 4 & $\begin{array}{l}\text { Siswa dapat membuat generalisasi } \\
\text { berdasarkan hasil penerapan prosedur } \\
\text { matematika }\end{array}$ & 223 & 179 & $71,93 \%$ & $57,74 \%$ \\
\hline \multicolumn{4}{|c|}{ Rata-rata Persentase Pencapaian } & $80,37 \%$ & $69,76 \%$ \\
\hline
\end{tabular}

\section{PEMBAHASAN}

Pembelajaran menggunakan model discovery learning sudah lebih baik daripada menggunakan model teacher centered. Hal ini dibuktikan bahwa pencapaian setiap indikator pada kelas eksperimen lebih baik dari pada kelas kontrol. Hasil penelitian di kelas eksperimen menunjukkan rata-rata dari empat indikator yang diterapkan dalam pedoman penskoran, indikator yang menilai tentang kemampuan siswa dalam membuat generalisasi berdasarkan prosedur matematika mempunyai nilai rata -rata yang paling rendah yaitu dengan nilai rata-rata $71,93 \%$. Hal ini dikarenakan bahwa siswa sering kali lupa akan menggeneralisasi dari hasil capaian yang telah mereka tulis atau kerjakan. Misalnya adalah, siswa sudah mengerjakan soal tes kemampuan literasi dari awal sampai akhir, namun ketika siswa sudah mencapai hasil yang mereka kerjakan sudah mendapatkan hasil, maka siswa merasa bahwa apa yang mereka kerjakan sudah selesai, padahal pada indikator penilaian kemampuan literasi matematika terdapat aspek penilaian sampai pada saat menggeneralisasi hasil akhir jawaban siswa yang sesuai dengan prosedur matematika.

Hasil penelitian ini menunjukkan bahwa pencapaian kemampuan literasi masih kurang maksimal di sekolah dasar. Penelitian sebelumnya dari Setiawati dkk (2013) juga mengemukakan bahwa keefektifan dalam meningkatkan literasi membaca berada pada kategori sedang. Karyono (2018) juga mengemukakan bahwa hasil ini juga disebabkan oleh minimnya integrase literasi dalam nilai-nilai pendidikan karakter yang diintegrasikan oleh guru dalam RPP, yitu hanya $10 \%$.

Siswa dapat mengkontruksi konsep-konsep dan pengetahuan baru yang dilakukan dengan cara menuliskan/mengembangkan penalarannya secara kritis dan kreatif sesuai dengan kemampuan berbahasa mereka (Mudiono, 2015). Salah satu indikator yang terkait dengan hal tersebut adala bagaimana siswa dapat menjawab soal tes kemampuan literasi matematika. Selama penelitian, siswa sangat antusias, mereka membaca soal yang diberikan dengan pemahaman yang sudah mereka ketahui. Siswa juga mampu menentukan kalimat matematika dari soal yang mereka baca, misalnya adalah memisahkan dan mengindentifikasi hal yang seharusnya menjadi pertanyaan, dan mana yang seharusnya menjadi diketahui. Hal ini terbukti bahwa pada indikator pertama dari penelitian ini adalah bagaiamana siswa dapat mengidentifikasi aspek-aspek matematis yang terdapat dalam bacaan matematika merupakan indikator yang mendapatkan rata-rata yang paling tinggi, yaitu $86,13 \%$.

Siswa menjawab pertanyaan dengan cara menuliskan apa yang diketahui, ditanyakan, dijawab dan dapat menyimpulkan dari pemecahan masalah secara berurutan juga sudah dikuasai oleh siswa dikelas eksperimen. hal ini terbukti bahwa pada indikatormenyusun komposisi dengan tepat yang terdapat dalam bacaan matematika sesuai konsep matematika di kelas eksperimen mencapai 83,44\%. Berbeda pada merancang dan menerapkan strategi dalam memecahkan masalah yang terdapat di soal 
terdapat beberapa siswa yang menulis tidak sesuai dengan prosedur perancangan yang ada dalam kaidah matematika. siswa sering menggunakan cara langsung saat menjawab soal yang mereka kerjakan. Permasalahan tersebut membuat aspek siswa untuk merancang dan menerapkan strategi dalam memecahkan masalah pada bacaan matematika dikelas eksperimen hanya mencapai persentase $80 \%$. Meskipun masih pada kriteria persentase yang baik, aspek ini dibawah rata-rata dari aspek yang kedua yaitu menyusun komposisi yang terdapat dalam bacaan matematika.

Pencapaian indikator kemampuan literasi matematika di kelas kontrol pada aspek siswa dapat mengidentifikasi aspek-aspek matematis yang terdapat dalam bacaan matematika dengan persentase $76,77 \%$, aspek siswa dapat menyusun komposisi dengan tepat yang terdapat dalam bacaan matematika sesuai konsep matematika dengan persentase $72,69 \%$ dan aspek siswa meracang dan menerapkan strategi dalam memecahkan masalah pada bacaan matematika dengan persentase $71,83 \%$ termasuk kedalam kategori baik hal ini sesuai dengan kriteria ketuntasan minimal yang digunakan di SDN Kalisari 1 yaitu sebesar 70 sedangkan pada aspek siswa dapat membuat generalisasi berdasarkan hasil penerapan prosedur matematika dengan persentase $57,74 \%$ termasuk dalam kategri tidak baik karena tidak mencapai kriteria ketuntasan minimasl yang digunakan di SDN Kalisari 1 yaitu sebesar 70 .

Persentase pencapaian indikator kemampuan literasi matematika tersebut menunjukkan bahwa terdapat perbedaan antara kelas eksperimen dan kelas kontrol. Persentase pencapaian indikator kemampuan literasi matematika dikelas eksperimen lebih baik dari pada dikelas kontrol dengan ratarata persentase pencapaian dikelas eksperimen sebesar 80,37\% dengan kategori baik dan di kelas kontrol sebesar 69,76\% dengan kategori tidak baik sehingga dapat disimpulkan bahwa kemampuan literasi matematika pada kelas eksperimen lebih baik dari pada kemampuan literasi matematika pada kelas kontrol. Kemampuan literasi matematika siswa lebih baik karena dalam proses pembelajaran dikelas eksperimen menggunakan model discovery learning.

Wahyuningtyas dkk (2017) mengemukakan bahwa penggunaan bahan ajar dalam penyajian konsep matematika masih kurang optimal sehingga siswa kesulitan memahami materi terutama pada materi geometri yaitu bangun datar dan bangun ruang. Dalam mengatasi hal tersebut, maka melalui model discovery learning siswa diberikan kesempatan untuk menemukan suatu konsep sendiri. Penemuan konsep tersebut dapat dilakukan dengan cara membaca. Siswa diberikan sebuah media pembelajaran komik yang digunakan untuk membantu menumbuhan kemampuan literasi matematika siswa melalui proses membaca dalam menemukan suatu konsep serta membantu siswa untuk dapat mengidentifikasi suatu bacaan. Selain komik, siswa juga diberikan sebuah tes kemampuan literasi matematika yang didalamya terdapat bacaan yang mengandung permasalahan-permasalahan untuk dipecahkan. Dari hasil tes kemampuan literasi matematika tersebut dapat dilihat bahwa dengan penggunaan model discovery learning ini mampu menumbuhkan kemampuan literasi matematika siswa menjadi lebih baik.

Hasil dari penelitian sesuai dengan teori yang dikemukakan oleh Thorndike. Thorndike mengemukakan bahwa belajar akan menimbulkan adanya stimulus dan respon(Lestari dan Yudhanegara, 2015). Stimulus yang sudah diberikan pada penelitian ini adalah berupa bacaan matematika. Pada penelitian yang telah dilakukan menunjukkan respon yang baik yaitu siswa mampu mengidentifikasi bacaan matematika melalui media yang diberikan guru, siswa mampu menyusun komposisi sesuai dalam bacaan, siswa mampu merancang strategi dalam memecahkan masalah siswa mampu menyimpulkan bacaan yang diberikan guru serta siswa mampu mengungkapkan pendapat berdasarkan bacaan atau stimulus yang telah diberikan.

\section{SIMPULAN DAN SARAN}

\section{Simpulan}

Hasil dari uji $t$ yang menunjukkan $t_{\text {hitung }}>$ $\mathrm{t}_{\text {tabel }}$, dengan $\mathrm{t}_{\text {hitung }}$ sebesar 3,16 dan $\mathrm{t}_{\text {tabel }}$ sebesar 2,04 artinya $\mathrm{H}_{0}$ ditolak dan $\mathrm{H}_{\mathrm{a}}$ diterima. Hal ini menunjukkan bahwa penggunaan model discovery learning efektif terhadap kemampuan literasi matematika siswa.

\section{Saran}

Berdasarkan temuan penelitian ini, disarankan bagi dosen Pendidikan Guru dan Sekolah Dasar untuk meningkatkan sosialisai mengenai model pembelajaran yang inovatif terhadap literasi 
kepada guru-guru sekolah dasar. Bagi lembaga Penelitian dan Pengabdian kepada Masyarakat (LPPM) agar memberikan motivasi kepada instansi untuk dapat mensosialisasikan kegiatan ini secara berkelanjutan. Bagi peneliti berikutnya dapat mengembangkan model pembelajaran yang lainya untuk meningkatkan literasi pada siswa sekolah dasar. Demikian pula bagi guru-guru sekolah dasar dapat mengimplementasikan dari hasil penelitian ini terkait dengan pembelajaran yang inovatif supaya lebih memahami kemampuan literasi matematika pada siswa di sekolah dasar.

\section{DAFTAR RUJUKAN}

Azhari. (2015). Penerapan Model Pembelajaran Discovery Learning Terhadap Peningkatan Hasil Belajar Siswa Kelas XI-IPA1 Pada Materi Sistem Pernapasan Di SMA Negeri Unggul Sigli. Jurnal Biologi Edukasi 7(1): 13-20. http://www.jurnal.unsyiah.ac.id.

Fathani, Abdul Halim. (2016). Pengembangan Literasi Matematika Sekolah Dalam Perspektif Multiple Intelligences. Jurnal EduSains 4(2): 136-50.

Hasnawati. (2016). Description Of Mathematics Literacy Ability of Students First Secondary School State 15 Kendari Based On Content, Context, Materials and Process. International Journal of Education and Research 4(4): 18596.

Hosnan, M. (2013). Pendekatan Saintifik dan Kontekstual dalam Pembelajaran Abad 21 Kunci Sukses Implementasi Kurikulum 2013. Jakarta: Ghalia Indonesia

Karso, dkk. (2009). Pendidikan Matematika I. Jakarta: Universitas Terbuka
Karyono, Hari. (2018). Revitalisasi Pendidikan Karakter Sejak Usia Dini di Kelas Rendah Sekolah Dasar. Sekolah Dasar 2(1): 10-18.

Kusumadewi, Rida Fironika. (2017). Menumbuhkan Kreativitas Calon Guru Sekolah Dasar Melalui Praktik Pembelajaran Matematika Berbantuan Media Ular Tangga. Ilmiah Pendidikan Guru Sekolah Dasar, 1(2), 188-194 1(2): 188-94.

Lestari dan Yudhanegara. (2015). Penelitian Pendidikan Matematika. Bandung: PT Refika Aditama

Mudiono, Alif. (2015). Pembelajaran Literasi Fokus Menulis Narasi Dengan Teknik Probing - Prompting Di SD. Sekolah Dasar 23(1): 3140. http://journal.um.ac.id/index.php/jurnalsekolah-dasar/article/view/6763.

Pulungan, Delyanti Azzumario. (2014). Pengembangan Instrumen Tes Literasi Matematika Model PISA. Journal of Educational Research and Evaluation 3(2): 2-6. http://journal.unnes.ac.id/sju/index.php/ jere\%0APENGEMBANGAN.

Setiawati, I. K., A. Rusilowati, and Khumaedi. (2013). Pembuatan Buku Cerita IPA yang Mengintegrasikan Materi Kebencanaan Alam untuk Meningkatkan Literasi Membaca dan Pembentukan Karakter. Jurnal Pendidikan IPA Indonesia 2(2): 129-35.

Wahyuningtyas, Dyah Tri, Nury Yuniasih, and Edy Bambang Irawan. (2017). Desain Modul Pembelajaran Geometri Dengan Pendekatan Contekstual Teaching And Learning Untuk Siswa Sekolah Dasar. Sekolah Dasar 2: 30-38.

Undang-undang Republik Indonesia No 20 Tahun 2003 Tentang Sistem Pendidikan Nasional. 